\title{
FUNGSI DAN JENIS MEDIA PEMBELAJARAN DALAM PEMBELAJARAN AKUNTANSI
}

\section{FUNCTIONS AND TYPES OF LEARNING MEDIA IN ACCOUNTING LEARNING}

\author{
Oleh : \\ Rizqi Ilyasa Aghni \\ Jurusan Pendidikan Akuntansi Universitas Negeri Yogyakarta \\ rizqiilyasa@uny.ac.id
}

\begin{abstract}
Abstrak
Pemilihan suatu jenis media pembelajaran merupakan salah satu bagian terpenting dalam proses pembelajaran di kelas. Pemilihan jenis media yang tidak tepat dapat menimbulkan berbagai efek dalam proses pembelajaran. Salah satu akibat yang paling sering ditemui adalah tidak maksimalnya proses pembelajaran yang terjadi di kelas. Hal ini akan menjadi penyebab utama tujuan akhir pembelajaran tidak tersampaikan dengan baik dan tidak dapat dicapai oleh peserta didik. Akuntansi merupakan salah satu mata pelajaran yang dikenal sebagai mata pelajaran yang memiliki perpaduan antara pemahaman konsep teori dan kemampuan eksak. Kondisi ini menuntut guru untuk lebih kreatif dalam menentukan jenis dan fungsi media yang terbaik dalam penyampaian materi di kelas. Dengan mengenal berbagai macam jenis dan fungsi media pembelajaran, diharapkan para guru dapat memilih dan menentukan jenis media pembelajaran yang terbaik untuk digunakan dalam proses pembelajaran di kelas.
\end{abstract}

Kata kunci : Media Pembelajaran, akuntansi, Fungsi, dan jenis

\begin{abstract}
Selection of a type of learning media is one of the most important parts in the learning process in the classroom. Selection of inappropriate media types can cause various effects in the learning process. One of the most common outcomes is the inadequate learning process that occurs in the classroom. This will be the main cause of the final goal of learning is not well conveyed and cannot be achieved by learners. Accounting is one of the subjects known as subjects that have a blend of understanding theoretical concepts and exact abilities. This condition requires teachers to be more creative in determining the type and function of the best media in the delivery of materials in the classroom. By knowing the various types and functions of instructional media, it is hoped that the teachers can choose and decide what kind of learning media is best for use in the learning process in the classroom.
\end{abstract}

Keyword: Learning Media, Accounting, Functions, and Types

\section{PENDAHULUAN}

Belajar adalah sebuah rangkaian proses yang terdiri dari banyak komponen, salah satunya adalah interaksi seseorang dengan lingkungannya (arsyad, 2014). Pertanda berhasilnya proses belajar adalah adanya perubahan tingkah laku dari orang yang belajar yang disebabkan oleh terjadinya perubahan tingkat pengetahuan, keterampilan dan sikapnya. Salah satu proses belajar yang dilakukan secara formal adanya proses pendidikan di sekolah. Dimana pendidikan formal ini dimaksudkan untuk mengarahkan perubahan pada 
diri siswa secara terarah, dan terencana, baik dalam hal pengetahuan, keterampilan, maupun sikap (arsyad, 2014).

Mata pelajaran akuntansi merupakan salah satu mata pelajaran yang memiliki tuntutan pemahaman konsep teori dan hitungan yang kuat secara bersamaan. Padatnya teori yang harus dikuasai oleh peserta didik dengan baik guna mendasari konsep perhitungan yang harus dikuasai berikutnya, menuntut guru untuk memilih media pembelajaran terbaik yang akan digunakan dalam kelas. Media pembelajaran yang saat ini banyak digunakan oleh guru cenderung masih bersifat konvensional seperti papan tulis, powerpoint, dan buku paket sebagai media cetak utama penyampai materi pada siswa. Dengan tidak maksimalnya pemilihan media ini pada akhirnya akan menggiring guru secara tidak langsung dalam pemilihan metode pembelajaran yang cenderung konvensional dan hanya terpusat pada guru.

Media pembelajaran adalah segala sesuatu seperti alat, lingkungan dan segala bentuk kegiatan yang dikondisikan untuk menambah pengetahuan, mengubah sikap atau menanamkan keterampilan pada setiap orang yang memanfaatkannya. (Arsyad, 2014). Pemilihan jenis media sering kali dipengaruhi oleh kemampuan guru dalam menggunakan media tersebut. Apabila guru memiliki keterbatasan kemampuan menggunakan jenis media tertentu akan membuat guru tersebut menghindari dalam menggunakan jenis media tersebut. Hal ini kemudian memberikan dampak pada keberagaman jenis media yang digunakan oleh guru menjadi semakin berkurang juga. Selain keterbatasan kemampuan penggunaan media, hal berikutnya yang dapat mempengaruhi pemilihan media adalah pengetahuan guru dalam mengenal fungsi dari suatu media pembelajaran. Tiap jenis media memiliki efek tersendiri yang akan ditimbulkan pada peserta didik. Efek ini dapat terkait dengan siapa pengguna media, bagaimana media tersebut digunakan, bagaimana media tersebut mempengaruhi penggunanya, dan bagaimana media tersebut cocok terhadap jenis materi yang akan disampaikan. Efek-efek ini kemudia dikenal sebagai fungsi pada media. Setelah guru mengenal fungsi berbagai media, kemudian menjadi acuan dalam menentukan jenis media (Kemp, 1975) yang sesuai dengan materi yang akan disampaikan pada peserta didik. Hal senada juga diungkapkan oleh Arief S. Sadiman (2009) bahwa klasifikasi media, karakteristik media, dan pemilihan media merupakan kesatuan yang tidak terpisahkan dalam penentuan strategi pembelajaran.

\section{KAJIAN TEORI}

\section{Pengertian dan Peran Media Pembela- jaran.}

Kata media berasal dari bahasa Latin, yakni Medius yang secara harfiah berarti 'tengah', 'perantara', atau 'pengantar' (Arsyad, 2014). Sedangkan Gerlach \& Ely memberi-kan penjelasan tentang media secara garis besar adalah manusia, materi, atau kejadian yang membangun kondisi yang dapat membuat siswa mampu memperoleh pengetahuan, keterampilan, atau sikap. Wina sanjaya (2014) menambahkan terkait definisi media sebagai perantara dari sumber informasi ke penerima informasi. Dari beberapa definisi tersebut dapat disimpulkan bahwa media adalah perantara baik berupa manusia, materi atau kejadian yang membantu membangun kondisi yang dapat membantu membuat peserta didik mampu memperoleh pengetahuan, keterampilan, atau sikap.

Berdasarkan definisi di atas dapat dilihat bahwa, media tidak hanya terkait dengan benda tetapi juga berupa kegiatan yang dapat membantu peserta didik dalam memahami materi yang diberikan oleh guru. Dalam kegiatan pembelajaran, definisi media akan lebih mengerucut pada fungsi media sebagai perantara yang dapat menunjang dan membantu siswa dalam memahami konsep materi pada proses pembelajaran. Media pembelajaran tidak terbatas pada alat saja, akan tetapi meliputi 
pemanfatan lingkungan baik yang didesain atau tidak untuk pembelajaran serta kegiatan yang sengaja dirancang untuk mencapai tujuan pembelajaran.

Daryanto (2013) memberikan penjelasan terkait beberapa kegunaan media pembelajaran yaitu 1) Memperjelas pesan agar tidak terlalu verbalistis. 2) Mengatasi keterbatasan ruang, waktu, tenaga, dan daya indra. 3) Menimbulkan gairah belajar, interaksi lebih langsung antara siswa dengan sumber belajar. 4) Memungkinkan siswa belajar mandiri sesuai dengan bakat dan kemampuan visual, auditori, dan kinestetiknya. 5) Memberi rangsangan yang sama, mempersamakan pengalaman dan menimbulkan persepsi yang sama. 6) Proses pembelajaran mengandung lima komponen komunikasi, guru (komunikator), bahan pembelajaran, media pembelajaran, siswa (komunikan), dan tujuan pembelajaran.

Kemp dan Dayton (1985) menjelaskan bahwa terdapat kontribusi yang sangat penting penggunaan media dalam proses pembelajaran yakni : 1) Penyampaian pesan pembelajaran dapat lebih terstandar, 2) Pembelajaran dapat lebih menarik, 3) Pembelajaran menjadi lebih interaktif dengan diterapkannya teori belajar dan prinsip-prinsip psikologi yang diterima dalam hal partisipasi siswa, umpan balik, dan penguatan, 4) Waktu pelaksanaan pembelajaran dapat diperpendek, 5) Kualitas pembelajaran dapat ditingkatkan, 6) Proses pembelajaran dapat berlangsung kapan pun dan di mana pun diperlukan, 7) Sikap positif siswa terhadap materi pembelajaran serta proses pembelajaran dapat ditingkatkan, 8) Peran guru berubah ke arah yang positif.

\section{Fungsi Media Pembelajaran}

Dalam proses pembelajaran, media pembelajaran memiliki beberapa fungsi. Wina sanjaya (2014) menjabarkan beberapa fungsi tersebut dalam beberapa jenis yaitu:

1. Fungsi komunikatif.
Media pembelajaran digunakan untuk memudahkan komunikasi antara penyampai pesan dan penerima pesan.

2. Fungsi motivasi.

Dengan menggunakan media pembelajaran, diharapkan siswa akan lebih termotivasi dalam belajar. Dengan demikian, pengembangan media pembelajaran tidak hanya mengandung unsur artistik saja akan tetapi juga memudahkan siswa mempelajari materi pelajaran sehingga dapat meningkatkan gairah belajar siswa.

3. Fungsi kebermaknaan.

Melalui penggunaan media, pembelajaran bukan hanya dapat meningkatkan penambahan informasi berupa data dan fakta sebagai pengembangan aspek kognitif tahap rendah, akan tetapi dapat meningkatkan kemampuan siswa untuk menganalisis dan menciptasebagai aspek kognitif tahap tinggi. Bahkan lebih dari itu dapat meningkatkan aspek sikap dan keterampilan.

4. Fungsi penyamaan persepsi

Melalui pemanfaatan media pembelajaran, diharapkan dapat menyamakan persepsi setiap siswa, sehingga setiap siswa memiliki pandangan yang sama terhadap informasi yang disuguhkan.

5. Fungsi individualitas.

Pemanfaatan media pembelajaran berfungsi untuk dapat melayani kebutuhan setiap individu yang memiliki minat dan gaya belajar yang berbeda.

Levie \& Lentz dalam (Azhar Arsyad, 2014) mengemukakan empat fungsi media pembelajaran, khususnya media visual, yaitu:

1. Fungsi atensi.

Fungsi atensi media visual merupakan inti, yaitu menarik dan mengarahkan perhatian siswa untuk berkonsentrasi kepada isi pelajaran yang berkaitan dengan makna visual yang ditampilkan atau menyertai teks materi pelajaran.

2. Fungsi afektif. 
Dapat terlihat dari tingkat kenikmatan siswa ketika belajar (atau membaca) teks yang bergambar. Gambar atau lambang visual dapat menggugah emosi dan sikap siswa.

3. Fungsi kognitif.

Terlihat dari temuan-temuan penelitian yang mengungkapkan bahwa lambang visual atau gambar memperlancar pencapaian tujuan untuk memahami dan mengingat informasi atau pesan yang terkandung dalam gambar.

4. Fungsi kompensatoris.

Media pembelajaran berfungsi untuk mengakomodasikan siswa yang lemah dan lambat menerima dan memahami isi pelajaran yang disajikan dengan teks atau disajikan secara verbal.

Jenis dan Pengelompokan Media Pembelajaran.

Perkembangan media pembelajaran saat ini dipengaruhi oleh banyak hal seperti perkembangan teknologi, ilmu cetak-mencetak, tingkah laku, dan komunikasi. Salah satu hal yang berkembang dari media adalah munculnya keberagaman jenis dan format media seperti modul cetak, film, televisi, program komputer dan lain sebagainya. Berdasarkan hal tersebut akhirnya dilakukanlah pengelompokan yang didasarkan kesamaan ciri atau karakteristik dari media. Yudhi Munadhi (2013) menjelaskan beberapa pengelompokan media tersebut terbagi dalam beberapa kelompok berikut :

\section{Klasifikasi Media Berdasarkan} Perkembangan Teknologi

Seels \& Glasgow membagi media berdasarkan perkembangan teknologi dalam dua klasifikasi, yaitu:

a. Media Tradisional,

1) Visual diam yang diproyeksikan : proyeksi overhead, slides, film stripe.

2) Visual yang tak diproyeksikan : gambar, poster, foto, chart, grafik.
3) Audio : rekaman piringan, pita kaset.

4) Penyajian multimedia : slide plus suara (tape), multiimage

5) Visual dinamis yang diproyeksikan : film, televisi, video.

6) Cetak : buku teks, modul, majalah ilmiah.

7) Permainan : teka-teki, simulasi.

8) Realia : model, specimen (contoh), manipiulatif (peta, boneka)

\section{b. Media Teknologi Mutakhir}

1) Media berbasis telekomunikasi : telekonferensi, kuliah jarak jauh.

2) Media berbasis mikroprosesor : komputer, interaktif, compact disk

2. Klasifikasi Media Berdasarkan Karakterisktik Stimulus yang Ditimbulkan.

Klasifikasi ini dikemukakan oleh Briggs dimana dikatakan bahwa pengelompokan media lebih mengarah pada karakteristik siswa, tugas instruksional, bahan dan transmisinya. Briggs mengklasifikasikan 13 macam media yang digunakan dalam proses pembelajaran, yaitu:

a) objek,

b) suara langsung,

c) media cetak,

d) papan tulis,

e) media transparansi,

f) film bingkai,

g) film rangkai,

h) film gerak,

i) televisi

j) gambar.

k) model,

l) rekaman audio,

m) pelajaran terprogram, 
Jurnal Pendidikan Akuntansi Indonesia, Vol. XVI, No. 1, Tahun 2018

Rizqi llyasa Aghni

$98-107$

Perhatikan gambar skema di bawah ini.

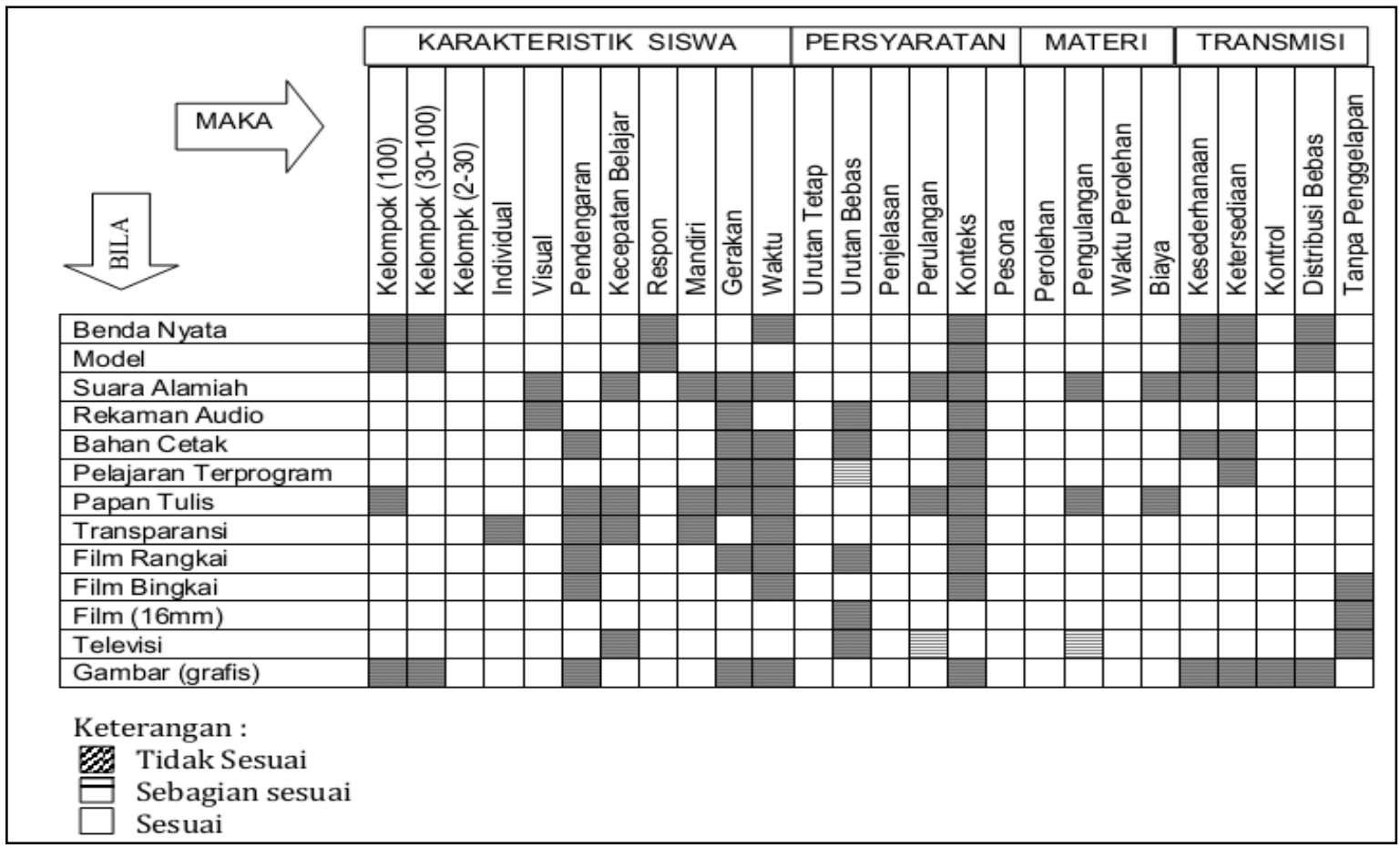

3. Klasifikasi Media Berdasarkan Indera yang Terlibat

Klasifikasi media ini dikemukakan oleh Rudy Bretz, yang menyatakan bahwa terdapat tiga ciri utama dalam pembagian media yaitu;

a) Ciri berdasarkan suara,

b) Ciri berdasarkan visual, yaitu;

1) Gambar

2) Garis

3) Simbol

c) Ciri berdasarkan gerak.
Selain berdasarkan ciri di atas, Bertz juga membedakan antara media siar (telecommunication) dan media rekam (recording), sehingga terdapat delapan klasifikasi media yaitu;

1) Media audio visual gerak

2) Media semi gerak,

3) Media audio visual diam,

4) Media audio, dan

5) Media visual gerak

6) Media cetak.

7) Media visual diam

Tabel berikut memperlihatkan skema klasifikasi media berdasarkan indera oleh Bretz :

\begin{tabular}{|l|l|l|l|l|l|l|}
\hline $\begin{array}{c}\text { MEDIA } \\
\text { TRANSMISI }\end{array}$ & SUARA & GAMBAR & GARIS & SIMBOL & GERAK & $\begin{array}{c}\text { MEDIA } \\
\text { REKAMAN }\end{array}$ \\
\hline AUDIO VISUAL GERAK & $\checkmark$ & $\checkmark$ & $\checkmark$ & $\checkmark$ & $\checkmark$ & Film/Suara \\
\hline & $\checkmark$ & $\checkmark$ & $\checkmark$ & $\checkmark$ & $\checkmark$ & Pita Video, Film TV \\
\hline Televisi (TV) & $\checkmark$ & $\checkmark$ & $\checkmark$ & $\checkmark$ & $\checkmark$ & Holografi \\
\hline & $\checkmark$ & $\checkmark$ & $\checkmark$ & $\checkmark$ & \\
\hline Gambar/Suara & $\checkmark$ & $\checkmark$ & $\checkmark$ & $\checkmark$ & & TV Diam \\
\hline AUDIO VISUAL DIAM & $\checkmark$ & $\checkmark$ & $\checkmark$ \\
\hline $\begin{array}{l}\text { Slow-Scan TV } \\
\text { Time-Shared TV }\end{array}$ & $\checkmark$ & $\checkmark$ &
\end{tabular}


Jurnal Pendidikan Akuntansi Indonesia, Vol. XVI, No. 1, Tahun 2018

Rizqi llyasa Aghni

$98-107$

\begin{tabular}{|c|c|c|c|c|c|c|}
\hline $\begin{array}{c}\text { MEDIA } \\
\text { TRANSMISI }\end{array}$ & SUARA & GAMBAR & GARIS & SIMBOL & GERAK & $\begin{array}{c}\text { MEDIA } \\
\text { REKAMAN }\end{array}$ \\
\hline & $\checkmark$ & $\checkmark$ & $\checkmark$ & $\checkmark$ & & Film Rangkai/Suara \\
\hline & $\checkmark$ & $\checkmark$ & $\checkmark$ & $\checkmark$ & & Film Bingkai/Suara \\
\hline & $\checkmark$ & $\checkmark$ & $\checkmark$ & $\checkmark$ & & Halaman/Suara \\
\hline & $\checkmark$ & $\checkmark$ & $\checkmark$ & $\checkmark$ & & Buku Dengan Audio \\
\hline \multicolumn{7}{|c|}{ AUDIO SEMI GERAK } \\
\hline \multirow[t]{2}{*}{ Tulisan Jauh } & $\checkmark$ & & $\checkmark$ & $\checkmark$ & $\checkmark$ & Rekaman Tulisan Jauh \\
\hline & $\checkmark$ & & $\checkmark$ & $\checkmark$ & $\checkmark$ & Audio Pointer \\
\hline \multicolumn{7}{|l|}{ VISUAL GERAK } \\
\hline & & $\checkmark$ & $\checkmark$ & $\checkmark$ & $\checkmark$ & Film Bisu \\
\hline \multicolumn{7}{|l|}{ VISUAL DIAM } \\
\hline & & $\checkmark$ & $\checkmark$ & $\checkmark$ & & Halaman Cetak \\
\hline & & $\checkmark$ & $\checkmark$ & $\checkmark$ & & Film Rangkai \\
\hline & & $\checkmark$ & $\checkmark$ & $\checkmark$ & & Seri Gambar \\
\hline & & $\checkmark$ & $\checkmark$ & $\checkmark$ & & Microform \\
\hline & & $\checkmark$ & $\checkmark$ & $\checkmark$ & & Arsip Video \\
\hline \multicolumn{7}{|l|}{ SEMI GERAK } \\
\hline Teleautograph & & & $\checkmark$ & $\checkmark$ & $\checkmark$ & \\
\hline \multicolumn{7}{|l|}{ AUDIO } \\
\hline Telepon Radio & $\checkmark$ & & & & & $\begin{array}{l}\text { Cakram (piringan) Audio } \\
\text { Pita Audio }\end{array}$ \\
\hline \multicolumn{7}{|l|}{ CETAK } \\
\hline Teletip & & & & $\checkmark$ & & Pia Berlubang \\
\hline
\end{tabular}

Pada akhirnya dalam proses pembelajaran dapat dikelompokkan menjadi 4 kelompok besar media, yakni sebagai audio media visual, media audio visual dan multimedia sebagaimana terlihat dalam tabel berikut:

\begin{tabular}{|c|l|l|l|l|l|}
\hline $\begin{array}{c}\text { Indera yang } \\
\text { Terlibat }\end{array}$ & \multicolumn{1}{|c|}{$\begin{array}{c}\text { Nama } \\
\text { Media }\end{array}$} & $\begin{array}{c}\text { Sifat } \\
\text { Pesan }\end{array}$ & \multicolumn{1}{c|}{$\begin{array}{c}\text { Program } \\
\text { (Software) }\end{array}$} & $\begin{array}{c}\text { Penyalur } \\
\text { (Hadware) }\end{array}$ & $\begin{array}{c}\text { Peralatan } \\
\text { proyeksi }\end{array}$ \\
\hline Pendengaran & Media & Audio & Radio & \\
& Audio & $\begin{array}{l}\text { verbal dan } \\
\text { nonverbal }\end{array}$ & $\begin{array}{l}\text { Piaram Radio } \\
\text { Siangsung } \\
\text { Siaranda (rekam) }\end{array}$ & & \\
\hline
\end{tabular}


Jurnal Pendidikan Akuntansi Indonesia, Vol. XVI, No. 1, Tahun 2018

Rizqi llyasa Aghni

$98-107$

\begin{tabular}{|c|c|c|c|c|c|}
\hline $\begin{array}{c}\text { Indera yang } \\
\text { Terlibat }\end{array}$ & $\begin{array}{l}\text { Nama } \\
\text { Media }\end{array}$ & $\begin{array}{l}\text { Sifat } \\
\text { Pesan }\end{array}$ & $\begin{array}{c}\text { Program } \\
\text { (Software) }\end{array}$ & $\begin{array}{c}\text { Penyalur } \\
\text { (Hadware) }\end{array}$ & $\begin{array}{c}\text { Peralatan } \\
\text { proyeksi }\end{array}$ \\
\hline & & & $\begin{array}{ll}\text { Program Audio } \\
\text { Rekam: } \\
\text { - } \quad \text { Sajian bahan diskusi } \\
\text { - } & \text { Entertain (musik) } \\
\text { - } & \text { Narasi } \\
\text { - } & \text { Dongeng } \\
\text { - } & \text { Darama, Poetry } \\
\text { - } & \text { Pengemb. Kosakata } \\
\text { - } & \text { Belajar konsep } \\
\text { - } & \text { Model (meniru suara, } \\
& \text { Nada, dll.) } \\
- & \text { dan lain-lain. } \\
\end{array}$ & 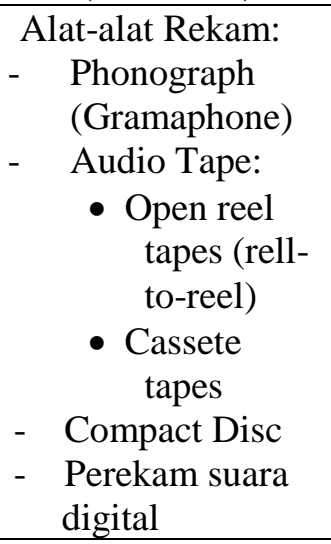 & \\
\hline \multirow[t]{7}{*}{ Penglihatan } & \multirow[t]{7}{*}{$\begin{array}{l}\text { Media } \\
\text { Visual }\end{array}$} & \multirow[t]{3}{*}{$\begin{array}{l}\text { Visual- } \\
\text { Verbal } \\
\text { Visual } \\
\text { Nonverbal } \\
\text { grafis }\end{array}$} & \multirow[t]{2}{*}{$\begin{array}{l}\text { Tulisan Verbal } \\
\text { Sketsa, lukisan, photo, } \\
\text { grafik, diagram, bagan, } \\
\text { peta }\end{array}$} & $\begin{array}{l}\text { Buku } \\
\text { Majalah } \\
\text { Koran } \\
\text { Poster } \\
\text { Modul } \\
\text { Komik } \\
\text { Atlas } \\
\text { Papan Visual } \\
\end{array}$ & $\begin{array}{l}\text { Opaque } \\
\text { Projector }\end{array}$ \\
\hline & & & & Transparasi & $\mathrm{OHP}$ \\
\hline & & & & komputer & $\begin{array}{l}\text { Digital } \\
\text { Projector }\end{array}$ \\
\hline & & \multirow{4}{*}{$\begin{array}{l}\text { Visual Non } \\
\text { ver-bal- } \\
\text { Tiga } \\
\text { Dimensi }\end{array}$} & \multirow[t]{4}{*}{ Model } & Maket (miniatur) & \\
\hline & & & & $\begin{array}{l}\text { Mock Up (alat } \\
\text { tiruan) }\end{array}$ & \\
\hline & & & & $\begin{array}{l}\text { Specimen (barang } \\
\text { contoh) }\end{array}$ & \\
\hline & & & & Diorama & \\
\hline \multirow{3}{*}{$\begin{array}{l}\text { Pendengaran } \\
\text { dan Pengliha- } \\
\tan \end{array}$} & \multirow{3}{*}{$\begin{array}{l}\text { Media } \\
\text { Audio } \\
\text { Visual }\end{array}$} & \multirow{3}{*}{$\begin{array}{l}\text { Verbal dan } \\
\text { Non-verbal, } \\
\text { ter-dengar } \\
\text { dan terlihat }\end{array}$} & \multirow{3}{*}{$\begin{array}{l}\text { Program audio visual: } \\
\text { Film Dokumenter } \\
\text { Docudokumenter } \\
\text { Film Drama } \\
\text { dan lain-lain }\end{array}$} & $\begin{array}{l}\text { Film } 8 \mathrm{~mm}, 16 \mathrm{~mm} \text {, } \\
35 \mathrm{~mm}\end{array}$ & $\begin{array}{l}\text { Film } \\
\text { Projector }\end{array}$ \\
\hline & & & & $\begin{array}{l}\text { Video: } \\
\text { Pita Magnetik } \\
\text { Video Disc } \\
\text { Chips Memory }\end{array}$ & $\begin{array}{l}\text { Digital } \\
\text { Projector }\end{array}$ \\
\hline & & & & Televisi & \\
\hline \multirow[t]{3}{*}{ Multi indera } & \multirow{3}{*}{$\begin{array}{l}\text { Multi- } \\
\text { media }\end{array}$} & \multirow{3}{*}{$\begin{array}{l}\text { Pengala- } \\
\text { man lang- } \\
\text { sung }\end{array}$} & \multicolumn{2}{|l|}{ Komputer } & \\
\hline & & & \multicolumn{2}{|c|}{$\begin{array}{l}\text { Pengalaman Berbuat: Lingkungan nyata dan } \\
\text { karyawisata }\end{array}$} & \\
\hline & & & \multicolumn{2}{|c|}{$\begin{array}{l}\text { Pengalaman Terlibat: Permainan dan Simulasi, } \\
\text { Bermain Peran dan Forum Teater }\end{array}$} & \\
\hline
\end{tabular}

\section{Karakteristik Pembelajaran akuntansi}

Proses pembelajaran akuntansi di dalam kelas identik dengan rangakaian latihan dan praktik dengan menggunakan contoh kasus dan soal-soal yang dapat membantu mengarahkan siswa pada kejadian riil berdasarkan konsep yang telah dipelajari sebelumnya. Pemberian tugas atau bentuk kegiatan pembelajaran di kelas dapat terkait dengan bermacam-macam ragkaian kegiatan yang meliputi : 1) mengidentifikasi data yang relevan dengan keputusan yang akan 
diambil, 2) memproses data yang relevan, 3) mengubah data menjadi informasi yang dapat digunakan menjadi dasar dalam pengambilan keputusan. (Jusup, 2005)

\section{METODE PENELITIAN}

Penelitian ini adalah sebuah penelitian studi pustaka dengan objek media pembelajaran yang digunakan dan dikembangkan pada proses pembelajaran akuntansi. Teknik pengumpulan data dengan studi dokumen, dan analisis data menggunakan metode kualitatif. Waktu penelitian yaitu FebruariMei 2018.

\section{HASIL PENELTIAN DAN PEMBA- HASAN \\ Kedudukan Media dalam Pembelajaran Akuntansi}

Media memiliki peranan yang sangat penting dalam proses pembelajaran akuntansi. Hal ini dikarenakan, siswa tidak hanya membutuhkan penjelasan secara konvensional dari guru, tetapi juga siswa membutuhkan sebuah wadah untuk dapat mengembangkan potensi yang ada pada diri siswa masing-masing dengan menggunakan media. Terlebih lagi bagi siswa yang memiliki gaya belajar yang berbeda-beda, dimana sangat mungkin bagi siswa yang memiliki ketidak cocokan gaya belajar dengan metode pembelajaran yang digunakan oleh guru akan mengalami kesulitan proses pembelajaran di dalam kelas. Berdasarkan hal inilah peranan media pembelajaran diharapkan untuk membantu memudahkan siswa dalam proses pembelajaran. Selain itu siswa juga dapat memahami materi tidak hanya dari penjelasan guru tetapi juga dapat belajar secara mandiri.

\section{Karakteristik Media Pembelajaran Akuntansi Berdasarkan Fungsinya}

Wina sanjaya (2014) menjelaskan bahwa media pembelajaran memiliki beberapa fungsi yaitu komunikatif, motivasi, kebermaknaan, penyamaan persepsi dan individualitas. Fungsi komunikatif dalam hal ini berkaitan dengan bagaimana media memberikan kemudahan pada guru dalam proses berkomunikasi dengan peserta didik untuk menyampaikan materi akuntansi baik materi yang bersifat teori maupun materi praktikum. Fungsi berikutnya adalah fungsi motivasi, dimana dengan menggunakan media pembelajaran, diharapkan siswa dapat lebih termotivasi dalam mengikuti proses kegiatan belajar di kelas. Terutama pada mata pelajaran praktikum, dimana siswa akan lebih bergairah dalam mengikuti pelajaran ketika guru menerangkan dengan menggunakan media yang dapat menarik perhatian maupun minat siswa.

Fungsi kebermaknaan berhubungan dengan bagaimana media pembelajaran akuntansi dapat memberikan kemampuan pada siswa tidak hanya dalam memahami materi akuntansi hingga pada tahap menganalisis dan mencipta, seperti mengolah dan menganalisis bukti transaksi hingga membuat laporan keuangan pada akhirnya. Fungsi ke empat yaitu fungsi penyamaan persepsi, dimana media pembelajaran akuntansi dapat membantu memberikan pandangan yang sama pada setiap siswa terhadap materi dan informasi yang disampaikan oleh guru. Fungsi yang teakhir yaitu fungsi individualitas. Fungsi ini berkaitan dengan bagaimana media pembelajaran akuntansi dapat memfasilitasi kebutuhan setiap individu yang berbedabeda atas berbagai macam model dan gaya belajar yang ada pada siswa.

\section{Jenis Media Pembelajaran yang Sesuai dengan Pembelajaran Akuntansi}

Berbagai jenis media pembelajaran telah banyak dikembangkan. Secara umum ada 4 jenis media pembelajaran yang dapat dikembangkan yaitu Media Audio, Media Visual, Media Audio-Visual, dan Multimedia. Dalam proses pembelajaran akuntansi terdapat beberapa jenis media pembelajaran yang sesuai dengan karakteristik pembelajaran akuntansi yaitu:

1) Media Visual

Jenis media ini berfokus pada penggunaan indera penglihatan Azhar Arsyad 
(2014). Penggunaan media visual dititik beratkan pada penyampaian pesan secara verbal maupun non verbal. Terdapat beberapa unsur-unsur pada media visual yang (Azhar Arsyad, 2014) mendukung kesesuaian penggunaan media visual dalam pembelajaran akuntansi yaitu :

a) Garis

Garis adalah kumpulan dari titiktitik. Penggunaan garis dalam pembelajaran akuntansi sangat penting peranannya. Salah satu fungsinya adalah mempertegas bentuk sebuah tabel pada pada tiap materi, menggambarkan alur siklus akuntansi dan lain sebagainya

b) Bentuk

Bentuk merupakan sebuah konsep simbol yang dibangun atas garis-garis atau gabungan dengan konsep lainnya. Dalam pembelajaran akuntansi, bentuk yang paling sering digambar adalah tabel. Tabel merupakan komponen yang sering digunakan dalam merangkum data-data ataupun menggambarkan susunan sebuah format pelaporan.

Media visual merupakan jenis media yang paling mendominasi dalam penggunaannya pada proses pembelajaran di kelas. Baik media visual yang sangat sederhana hingga ke media visual yang kompleks seperti penggunaan papan tulis, media presentasi, buku teks, dan alat peraga.

2) Media Audio-Visual

Media audio-visual merupakan perpaduan antara media yang berkonsentrasi pada penggunaan audio dengan media yang berkonsentrasi pada penggunaan visual. Media ini biasanya dibuat dalam bentuk video, film pendek, gambar / slide bersuara atau lainnya. Dalam pembelajaran akuntansi, jenis media ini sangat mendukung sekali untuk mengembangkan keterampilan motorik peserta didik. Terutama media dalam bentuk video tutorial, sangat bermanfaat sekali dalam menunjang proses pembelajaran praktikum komputer akuntansi. Dimana dengan menggunakan video tutorial ini, siswa dapat mengulang-ulang secara mandiri penjelasan dan praktik yang telah direkam apabila terdapat hal yang belum dipahami. Dan ini tentunya akan sangat membantu guru dalam mengefisienkan waktu dalam proses pembelajaran di kelas.

Selain video tutorial, saat ini juga banyak dikembangkan video animasi yang memadukan gambar bergerak dan suara narator. Gambar bergerak memberikan ilustrasi pada materi yang sedang di jelaskan, dan suara narator memberikan penjelasan secara audio kepada penonton. Dalam pembelajaran akuntansi, tentu media ini sangat cocok pada bagian penanaman pemahaman konsep dan teori, sehingga banyak sekali digunakan dan dikembangkan oleh para pendidik. Beberapa website penyedia jasa pembuatan video animasi ini seperti Go Animate, Video Scribe, Powtoon, Moovly, dan lain sebagainya.

\section{3) Multimedia}

Multimedia adalah jenis media paling kompleks dari keseluruhan jenis media yang ada. Karakter utama multimedia adalah adanya interaksi dan kesempatan pengguna untuk mengontrol media menggunakan alat kontrol yang tersedia pada media. Pada pembelajaran akuntansi penggunaan multimedia ini banyak digunakan dalam bentuk aplikasi permainan (Game) berbasis komputer ataupun android. Aplikasi permainan ini sering digunakan untuk membantu menanamkan konsep materi, dan pengayaan materi di luar jam pelajaran. Sehingga siswa dapat lebih memiliki ketertarikan dalam mengakses materi akuntansi tidak hanya di kelas pada jam pelajaran, namun juga di luar kelas pada saat di luar jam pelajaran.

Adapun bentuk lain dari multimedia yang digunakan adalah penggunaan software simulasi siklus akuntansi seperti $M Y O B$, Accurate, Zahir, dan lain sebagainya. Berbagai macam aplikasi ini membantu siswa dalam memahami siklus akuntansi secara praktik terkomputerisasi. Tidak 
hanya keterampilan yang dikembangkan tetapi juga pematangan pemahaman konsep akan dapat diperoleh oleh siswa ketika menggunakan aplikasi simulasi ini.

\section{SIMPULAN DAN SARAN \\ Simpulan}

Dalam pembelajaran akuntansi, fungsi media pembelajaran memiliki peran yang sangat penting. Media pembelajaran tidak hanya sebagai pelengkap dalam proses pembelajaran tetapi juga menjadi salah satu faktor penentu keberhasilan proses pembelajaran di kelas. Media pembelajaran memiliki beberapa fungsi yaitu komunikatif, motivasi, kebermaknaan, penyamaan persepsi dan individualitas. Kelima fungsi ini memberikan penjelasan bahwa media pembelajaran memiliki dampak yang positif pada proses pembelajaran. Tidak hanya berdampak bagi perkembangan kognitif siswa tetapi juga daya imajinasi dan keterampilan siswa dapat di kembangkan menggunakan media pembelajaran.

Beberapa jenis media pembelajaran yang dapat dikembangkan dan diterapkan pada proses pembelajaran akuntansi yaitu 1) Media Visual, 2) Media Audio-Visual, dan 3) Multimedia. Ketiga jenis media ini memiliki keunggulan dan kekurangannya masing-masing. Pemilihan jenis media pembelajaran yang tepat dapat memberikan kemudahan dalam proses transfer materi dari guru ke siswa, sehingga proses pembelajaran dapat berjalan lebih efektif dan efisien.

\section{Saran}

Dengan beragamnya jenis media ini, diharapkan guru dapat memperhatikan dan mengikuti perkembangan jenis media pembelajaran yang ada. Tidak hanya mengandalkan media pembelajaran yang bersifat konvensional seperti papan tulis, buku tulis, LKS dan powerpoint, tetapi juga berani mencoba untuk menggunakan jenis media lainnya yang lebih kompleks seperti video animasi ataupun bahkan membuat aplikasi interaktif yang dapat merangsang kemampuan kognitif dan motorik siswa secara bersamaan. Hal ini tentunya dapat disesuaikan dengan jenis dan karakteri materi yang akan diajarkan pada siswa, karena tidak semua jenis materi pelajaran akan selalu cocok dengan jenis media pembelajaran tertentu.

\section{DAFTAR PUSTAKA}

Arsyad, Azhar. 2014. Media Pembelajaran. Jakarta : PT. Raja Grafindo Persada

Daryanto. 2013. Media Pembelajaran. Yogyakarta : Gava Media

Gerlach, V.G. \& Ely, D.P. 1971. Teaching and Media. A Systematic Approach. Englewood Cliffs: Pentice Hall Inc.

Jusup, Al.Haryono. 2005. Dasar-dasar Akuntansi.Yogyakarta : Sekolah Tinggi Ilmu Ekonomi YKPN

Kemp, Jerrold E. Dayton. Diane K. 1985. Planning \& Producing Instructional Media Fifth Edition. New York: Harper \& Row Publisher

Munadhi, Yudhi. 2013. Media Pembelajaran: Sebuah Pendekatan Baru. Jakarta: Referensi

Sadiman, Arief, R. Rahardjo, Anung Haryono, Rahardjito. 2009. Media Pendidikan Pengertian, Pengembangan, dan Pemanfaatannya. Jakarta: Raja Grafindo Persada

Sanjaya, Wina. 2014. Media Komunikasi Pembelajaran. Jakarta : Kencana. 